\title{
AUTHOR'S PROGRAMS ON CONTEMPORARY TELEVISION AND THEIR PECULIARITIES
}

\author{
Svitlana Kotliar ${ }^{1 a}$, Oleksandr Butko ${ }^{2 a}$, Nataliia Krochak ${ }^{3 a}$ \\ ${ }^{1}$ Honored Art Worker of Ukraine, Professor of the Television Journalism \\ and Acting Department, Dean of the Faculty of Cinema and Television; \\ e-mail: ilanit1925@gmail.com; ORCID:0000-0002-4855-8172 \\ ${ }^{2}$ Honoured Journalist of Ukraine, Associate Professor of the Television Journalism \\ and Acting Department; e-mail: butko2016@ukr.net; ORCID: 0000-0002-5054-284X \\ ${ }^{3}$ Master's Student, Television Journalism and Acting Department; \\ e-mail: krochak4455@icloud.com; ORCID: 0000-0002-8920-8144 \\ ${ }^{a}$ Kyiv National University of Culture and Arts, Kyiv, Ukraine
}

\section{Keywords:}

author's program; anchor-author; program; genre; format; television

\begin{abstract}
The purpose of this research is to analyze the main features of the author's programs on modern television. The research methodology includes such methods as analysis and synthesis (the presence and significance of author's programs on Ukrainian TV channels are analyzed), generalization (based on the analyzed literature and real air product the factors, features, peculiarities that reveal the essence of author's programs are summarized), systematization. The scientific novelty consists in the detailed analysis of signs of author's programs and their features on television; in an attempt to create their classification by type, depending on the genre format, the contribution of the author's "ego", the scope and forms of work on the material. Conclusions. During the study of foreign author's programs, their features on Ukrainian channels were analyzed in the literature of theorists and practitioners of film and television. It was found that there are few author's programs created by leading authors in Ukraine and most of them are narrowbranch. The types of this genre of programs have been studied. The peculiarities of the author's programs on modern television have been generalized.
\end{abstract}

For citation:

Kotliar, S., Butko, O. and Krochak N. (2020). Author's programs on contemporary television and their peculiarities. Bulletin of Kyiv National University of Culture and Arts. Series in Audiovisual Arts and Production, 3(2), pp.222-228.

\section{Problem Statement}

Today, in the pursuit of ratings, leading Ukrainian TV channels are buying program formats, while regional ones are following a simpler path - buying ready-made secondary content. TV channel owners do not want to invest their own money in the production because they do not trust experts. It is your own product and 
especially the author's programs that are the broadcaster's business card. It should be noted that recently the concept of "author's program" has begun to develop. This is due to its "appropriation" by the authors of programs of various traditional genres in order to create the image of innovators and become one with the stars of television. Researchers quite demandingly outline the framework, substantiate the features and analyze the issues of genre formats of author's programs. Examining the compliance of modern author's programs of the Ukrainian television space, the criteria of this type of television, they tried to classify these programs by genre formats.

\section{Recent research and publications analysis}

Ukrainian and foreign researchers pay attention to a number of mandatory features of the author's programs. R. Shyrman (2008), V. Moiseiev (2002) emphasize the uniqueness of the created product. The topic of genre formats is covered by S. Kotliar and V. Fedorenko (2018).

\section{Purpose of the article}

The purpose of the research is to analyze the main peculiarities of the author's program on modern TV.

\section{Main research material}

At the beginning of the $21^{\text {st }}$ century, the term "author's program" has become widely used not only on leading TV channels but also on regional ones, where most TV programs are incorrectly called by this term, even if they are ordinary interviews with local officials. There were attempts on Belarusian television to introduce music programs composed of works by various composers and poets, they began to be called "author's" (competition of young performers "Zaspivai" [Sing] in the program of host Sergei Budkin "Belsat Music Live" on "Belsat").

The widely used term author's TV program glorifies the role of presenters and TV journalists and creates a positive image.

Most programs cover long-established genres of journalism, such as reporting, interviews, essays, reviews, feuilletons, and more. The author's program has its own position and criteria. Scientists have different opinions about this, but agree on one thing: these criteria must be very high. It is worth agreeing with the opinion of V. Moiseiev, who noted that the author's program can be considered only such a program to which the TV journalist has the rights in accordance with the current legislation of Ukraine (2002, p.221). S. Kotliar and V. Fedorenko $(2018$, p.8) emphasize the importance of the figure of a TV anchor who would meet the tastes of viewers and be a specialist. In their opinion, the figure of the TV presenter in the frame is the biggest factor influencing the consciousness of the mass audience.

Well-known director, Professor Roman Shyrman in his book "Alchemy of Directing" equates the author's programs to the level of cinema. In addition, he considers one of the key criteria of the author's program the unusualness of the presenter. He cites the example of the well-known journalist Leonid Parfionov, who "in his films allows himself great liberties: he climbs out with his feet, for example, into a closet-like bed of Peter I in a Dutch boarding house. He dreams of the streets of a German city with 
a long oar in his hands" (Shyrman, 2008, p.232-233).

During the analysis of the author's program, it is necessary to give a definition from the "New Explanatory Dictionary of the Ukrainian language": The author's television is based on a vividly depicted idea, position and search in the field of artistic form of the program" (2000, p.47).

Examining the author's programs, we can note a different classification.

Thus, in particular, T. Kovtun in the "Great Ukrainian Encyclopedia" notes: "There are the following types of author's programs:

1) information-analytical ("Facts of the week with Oksana Sokolova", "TSN week" by Alla Mazur);

2) journalistic "Shuster live" by Savik Shuster, "People. Hard Talk" by Natalia Vlashchenko);

3) entertainment and games ("Secular life with Kateryna Osadcha", "The world inside out with Dmitry Komarov")" (2020).

R. Shyrman (2008, p.234) divides the author's programs into:

1) studio talk shows - a genre in which there is a television discussion;

2) author's programs - a genre in which there is an original idea and author's opinion;

3) author's films - an audiovisual work on which authors, producers and actors work.

In view of the above, we can consider such a concept as the genre format, which was studied by S. Kotliar and V. Fedorenko $(2018$, p.9): allows you to reveal a specific topic, to identify their creative potential".

After analyzing the research of scientists, as well as the author's programs available on Ukrainian television, we can offer our own vision of their main types in genre formats (in ascending order of the hypothetical volume of the author's work on one program):
1. Studio author's talk shows.

There are a lot of them live lately. These are mostly topical political, social, and less often economic or cultural debates. The most famous TV presenters Nataliia Mosiichuk ("1+1"), Savik Shuster ("Ukraine"), Yevhen Kiseliov (traveled on the route "Inter" - "112" - "NewsOne" "Live" - "Ukraine24"), Andrii Palchevskyi ("112" and "NewsOne"), Petro Maga ("112"), Matvey Ganapolsky ("Direct"), and, until recently, Andrii Kulikov ("ICTV"). They are, of course, authors, because they choose topics and guests, periodically express their own points of view, but, rather, moderators - direct and control the conversation in which the main messages are spoken by guests.

2. Author's monologue programs.

Studio author's talk shows, which in 2010 occupied a large share of television content. Let's analyze the programs "Silver Ball" ("Serebryanyj Shar" (later "My Silver Ball" by Vitaly Wolf and "To Remember" ("Chtoby pomnili) by Leonid Filatov on Russian TV. A. Yurievskiy (2003) once wrote about the transfer of Vitaly Wolf: "And what exactly is in this program? A man sits without a tie in a small, darkened studio, almost no scenery, tells, shows newsreels, recalls personal meetings... All "No expensive newsrooms, no elegant shooting or editing".

There are no author's programs of this kind on Ukrainian television. Analyzing the programs of Vakhtang Kipiani, Volodymyr Voitenko, Roman Vintoniv (there are many more names), it should be noted that their programs are not author's monologues, but highly professional handling of facts and their skilful cutting.

3. Author's program of reportage type.

In Ukraine, the brightest examples are "The World Inside Out with Dmytro 
Komarov", "Secular Life with Kateryna Osadcha" and Andrii Tsaplienko's reportage documentaries. Olga Freimut's programs "Inspector" ("New Channel") and "Inspector Freimut" ("1+1") were popular on television at one time.

The format of "The World Inside Out with Dmitry Komarov" provides for the opening of previously unknown places for the viewer, acquaintance with the traditions and laws of different countries so that their cultural values become the property of a wide audience. Komarov risks his own life by approaching dangerous animals or performing dangerous tricks. And all for the sake of getting a spectacular shot. The author works without a pre-prepared script and is able to shoot a quality TV program about travel.

The Secular Life with Kateryna Osadcha project is a series of provocative reportage interviews. Osadcha herself in her avantgarde hat is part of the show. No social event takes place without it, because the whirlpool of stellar events is the main thing in the project. Osadcha is not denied an interview by the world's biggest stars actors, politicians, musicians, fashion designers. Ukrainian bohemians are also trying to get into the program, despite the fact that they are always exposed to scathing questions. Scripted in a chain, supplemented by additional "yellow" information about the characters in the captions, filmed in a non-standard way by moving cameras, these interviews are eventually combined into an author's program.

Andrii Tsaplienko is often in the "hot spots" of the planet, but from there he prepares not only reports, but also entire investigation programs with historical background, author's analysis and forecast of developments.
Olga Freimut investigated the social sphere but the development of her career in the field of auteur television was hampered by litigation between TV channels over the format of her programs.

4. author's programs-films.

Such programs can be considered as multi-component works with an original plot, often with a non-standard view of phenomena, events, facts of history.

This category includes part of the work of the already mentioned Andrii Tsaplienko (for example, the film "The City Who Betrayed", which was nominated for the Taras Shevchenko National Prize of Ukraine).

Until recently, Svitlana Usenko worked in this field. Her documentaries

"Secrets of Taras Shevchenko", "Secrets of Bandera", "Split into Atoms", "Children of Victory" were shown on the 1+1 TV channel with high ratings.

The work by Kharkiv journalist Ihor Piddubnyi is unparalleled. He creates documentary films, in which he sometimes seeks to imitate Leonid Parfionov. These are studies on the verge of scientific discoveries - "Return" ("Vozvrashchenye") - the search for the remains of Yaroslav the Wise with specially ordered and documented DNA analysis in laboratories in the US and Canada, historical intelligence - "Crimea. Strict regime resort" ("Krym. Kurort Strohoho Rezhyma") - about the real history of the peninsula from 1783 to 1991, "In August of 1943" ("V avguste 43-go") - the whole truth about the liberation of Kharkiv from fascist invaders, documentary detectives "Ivan Mazepa. I appoint you a traitor" ("Ivan Mazepa. Naznachayu tebya predatelem"), provocative "puns" - "Ukraine" - unknown pages of the USSR collapse and reflections on whether Ukraine could adapt after 1991. 
I. Dolzhenkova criticized the content of the last of these films in "Media Detectors" (2016) (she called it "a pun").

It is worth arguing with this statement because her remarks concern only the content, not the creative search, the skill of the journalist. Note that I. Piddubnyi's films, although patriotic, are in Russian. Probably, that is why they were not aired on major all-Ukrainian private channels. Only "Crimea. Strict regime resort" was shown by "UA: The First", and "Return" and "Ukraine" by TV channel "Tonis".

It is worth agreeing with T. Kovtun, the author's programs can also be considered the final information weekly, such as: "TSN. A week with Alla Mazur" (" $1+1$ ") or "Facts of the week with Oksana Sokolova" ("ICTV"). These presenters, according to the figurative expression of $\mathrm{T}$. Kovtun (2020), "play the piano", which is "worn, tuned, cared for" by other participants in the process. Sometimes in such programs, intelligent and skilled editors play a significantly more important role than presenters (Kovtun, 2020).

An example is the program "Big Football with Alexander Denisov", which until 2003 was close to the author's format, as Alexander Denisov was the host, editor and author of some stories. Recently, his role as an author has actually diminished, and the program has been created by a large group of television professionals.

Analyzing the content of TV channels in terms of the highest requirements for authoring programs, it should be noted that not all programs that are marked in the program grid as author's, are such in fact.

\section{Conclusions}

It can be concluded that in the era of modern commercial television there are very few author's programs and their number is not significant for the popularity of the channel. It takes money, ideas, time and experience to create a unique program. Ukrainian television is not ready to take risks for the sake of the audience. In their opinion, it is safer to buy an already wellknown product for the whole world, which had huge ratings, and to process it for Ukraine. And almost all such purchases have paid off. The author's program provides a large number of requirements: professionalism, confidence, professional competence, ability to take risks. Therefore, its creation is the pinnacle of TV journalism and the full interaction of the viewer and the host-author.

\section{REFERENCES}

Dolzhenkova, I., 2016. "Ukraia" - provokatsiia chy shyzofreniia? ["Ukraine" - a provocation or schizophrenia?]. Detektor media. [online] 23 August 2016. Available at: <https://detector.media/ kritika/article/118060/2016-08-23-film-ukraya-provokatsiya-chi-shizofreniya/> [Accessed 29 April 2020].

lurevskii, A., 2003. Teleiavlenie [Television]. [online] Available at: <https://web.archive.org/ web/20041225093929/http:/www.lgz.ru:80/archives/html_arch/lg402004/Polosy/art9_4.htm> [Accessed 04 May 2020].

Kotliar, S.V. and Fedorenko, V.P., 2018. Avtorska prohrama - oblychchia ukrainskoho telebachennia [Author's program - the face of Ukrainian television]. Visnyk Kyivskoho natsionalnoho universytetu kultury i mystetstv. Seriia: Audiovizualne mystetstvo i vyrobnytstvo, 1, pp.5-17. 
Kovtun, T.V., 2020. Avtorska prohrama na telebachenni [Author's program on television]. Velyka ukrainska entsyklopediia. [online] Available at: <https://vue.gov.ua/Avtors'ka_prohrama_na_ telebachenni> [Accessed 04 May 2020].

Kulchynska, L., 2010. Poniattia "kinozhanru": problema definitsiï [The concept of "film genre": the problem of definition]. Academic bulletin of kyiv national karpenko-karyi university of theatre, cinema and television, 6, pp.143-156.

Moiseev, V.A., 2002. Zhurnalistika i zhurnalisty [Journalism and Journalists]. Kyiv: Dakor. Rizun, V.V., 2008. Teoriia masovoï komunikatsiï [Theory of mass communication]. Kyiv: Prosvita. Shirman, R.N., 2008. Alkhimiia rezhissury [The Alchemy of Directing]. Kyiv: Teleradiokurer.

Sventakh, A., 2015. "Krym. Kurort suvoroho rezhymu" ["Crimea. A strict regime resort"]. Den, 23 October.

Yaremenko, V. and Slipushko, O., editor-in-chief., 2000. Novyy tlumachnyy slovnyk ukraïnskoï movy [A new explanatory dictionary of the Ukrainian language]. Kyiv: Akonit. Vol. 1.

\title{
АВТОРСЬКІ ПРОГРАМИ НА СУЧАСНОМУ ТЕЛЕБАЧЕННІ ТА ÏХНІ ОСОБЛИВОСТІ
}

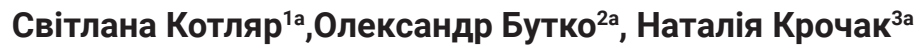

\author{
${ }^{1}$ заслужений діяч мистецтв України, професор кафедри тележурналістики та майстерності актора, \\ декан факультету кіно і телебачення; e-mail: ilanit1925@gmail.com; ORCID: 0000-0002-4855-8172 \\ 2 заслужений журналіст України, доцент кафедри тележурналістики та майстерності актора; \\ e-mail: butko2016@ukr.net; ORCID: 0000-0002-5054-284X \\ ${ }^{3}$ магістрант кафедри тележурналістики та майстерності актора; \\ e-mail: krochak4455@icloud.com; ORCID: 0000-0002-8920-8144 \\ а Київський національний університет культури і мистецтв, Київ, Україна
}

\begin{abstract}
Анотація
Мета дослідження - провести аналіз основних особливостей авторських програм на сучасному телебаченні. Методологія дослідження. Використано методи: аналіз та синтез (проаналізовано наявність і значущість авторських програм на телеканалах України), узагальнення (на основі проаналізованої літератури та реального ефірного продукту підсумовано чинники, риси, особливості, що розкривають суть авторських програм), систематизація. Наукова новизна полягає у детальному аналізі ознак авторських програм та їх особливостей на телебаченні; у спробі створити їхню класифікацію за видами, залежно від жанрового формату, вкладу авторського «его», обсягу і форм роботи над матеріалом. Висновки. Під час дослідження закордонних авторських програм їх особливостей на українських каналах було проаналізовано літературу теоретиків та практиків кіно-, телемистецтва. Виявлено, що в Україні мало авторських програм, які створюються ведучими-авторами і більшість з них вузькогалузеві. Досліджено види цього жанру програм. Узагальнено особливості авторських програм на сучасному телебаченні.
\end{abstract}

Ключові слова: авторська програма; ведучий-автор; програма; жанр; формат; телебачення 


\title{
АВТОРСКИЕ ПРОГРАММЫ НА СОВРЕМЕННОМ ТЕЛЕВИДЕНИИ И ИХ ОСОБЕННОСТИ
}

\author{
Светлана Котляр ${ }^{1 a}$, Александр Бутко ${ }^{2 a}$, Наталия Крочак ${ }^{3 a}$ \\ ${ }^{1}$ заслуженный деятель искусств Украины, профессор кафедры тележурналистики и мастерства актера, \\ декан факультета кино и телевидения; e-mail: ilanit1925@gmail.com; ORCID: 0000-0002-4855-8172 \\ 2 заслуженный журналист Украины, доцент кафедры тележурналистики и мастерства актера; \\ e-mail: butko2016@ukr.net; ORCID: 0000-0002-5054-284X \\ ${ }^{3}$ магистрант кафедры тележурналистики и мастерства актера; \\ e-mail: krochak4455@icloud.com; ORCID: 0000-0002-8920-8144

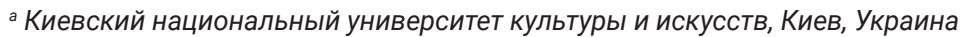

\begin{abstract}
Аннотация
Цель исследования - провести анализ основных особенностей авторских программ на современном телевидении. Методология исследования. Использованы методы: анализ и синтез (проанализировано наличие и значимость авторских программ на телеканалах Украины), обобщение (на основе проанализированной литературы и реального эфирного продукта подытожены факторы, черты, особенности, раскрывающие суть авторских программ), систематизация. Научная новизна заключается в детальном анализе признаков и особенностей авторских программ на телевидении; в попытке создать их классификацию по видам, в зависимости от жанрового формата, вклада авторского «эго», объема и форм работы над материалом. Выводы. В ходе исследования зарубежных авторских программ и их особенностей на украинских каналах была проанализирована литература теоретиков и практиков кино-, телеискусства. Выявлено, что в Украине мало авторских программ, которые создаются ведущими-авторами и большинство из них узкоотраслевые. Были исследованы виды данного жанра программ. Проведен обзор особенностей авторских программ на современном телевидении.
\end{abstract}

Ключевые слова: авторские программы; ведущий-автор; программа; жанр; формат; телевидение 